\title{
Microseismic monitoring application for primary stability evaluation of the powerhouse of the Tapovan Vishnugad Hydropower Project
}

\author{
Vikalp Kumar ${ }^{1,2, *}$, N Gopalakrishnan ${ }^{3}, \mathrm{~N}^{\mathrm{P}} \mathrm{Singh}^{2}$ and Sivakumar Cherukuri ${ }^{1}$ \\ ${ }^{1}$ National Institute of Rock Mechanics, Bengaluru, India. \\ ${ }^{2}$ Department of Geophysics, Institute of Science, Banaras Hindu University, Varanasi, India. \\ ${ }^{3}$ NTPC Ltd., Joshimath, Uttarakhand, India. \\ *Corresponding author. e-mail: vikalpk@gmail.com
}

MS received 17 November 2017; revised 28 January 2019; accepted 17 February 2019; published online 17 June 2019

The study of micro-cracks, shear zone and redistribution of stress after excavation in the rockmass is required for a stability analysis of the underground structure. The powerhouse of the Tapovan Vishnugad Hydropower Project (TVHPP) of NTPC Ltd. is located in the seismic zone V of India and is positioned at the junction of the middle and higher Himalayan region under challenging geological conditions. The powerhouse cavern constructed by drill and blast method encountered a number of rockbursts of various intensities during and after construction. So, a real-time remote microseismic monitoring network was used to evaluate the stability of the powerhouse cavern rockmass. Strata condition, rockburst occurrence during construction and drilling feasibility for sensor installation were studied for an array of designs of the microseismic monitoring network. The primary monitoring period demarcated the micro-crack locations and probable failure zones in the powerhouse rockmass by processing and analysis of various temporal and spatial variations of microseismic parameters to evaluate the underground powerhouse structural stability. Although a large number of microseismic events occurred in the powerhouse which resulted in high displacement in a few areas, due to the low amount of energy released from the events occurring inside the powerhouse, the structure appears to be stable.

Keywords. Microseismic monitoring; powerhouse; rockburst; TVHPP; stability.

\section{Introduction}

Excavation in the rock mass results in stress redistribution in the surrounding rock that may lead to a violent failure of rocks. When rock mass failure occurs, it may emit seismic waves, which is defined as induced seismicity. Such induced seismicity might cause damages to the excavated structure and the associated damage with the seismic event is referred as rockburst. A rockburst is defined as a sudden and sometimes violent release of accumulated energy when a volume of rock is strained beyond its elastic limit (Scott et al. 1997). Bennett and McLaughlin (1997) defined rockburst as 'Any type of stress-release phenomenon which has been induced by mining activity and which results in emission of seismic signals'. Rock mass failure is a major problem in underground excavations and excavations in the Great Himalayan mountain (Panigrahi 2013). In the Himalayan 
region, various rockbursts occur during and after the excavation for the underground caverns and highways.

Rock burst is a common phenomenon observed in deep underground mines such as the Kolar Gold Fields (KGF), Karnataka. KGF is one of the oldest mining areas in the world, where the mining activity reached a depth of about $3.35 \mathrm{~km}$. Rockbursts have been reported due to the sudden collapse of underground workings in the mine since the beginning of the past century. The first one was recorded and reported in 1902 by Dr W F Smeeth, the chief inspector of mines (Behera 1989). One of the most severe rockbursts was of a magnitude 4.6 on the Richter scale that was recorded by a number of seismological observatories in India (Guha 1982). Similar rock burst problems also occur in the deep gold mines of South Africa (Durrheim et al. 2011). Rockbursts still occur in the KGF even after the closure of the mines.

India has been classified into four seismic zones, namely, zones II, III, IV and V on the basis of seismicity (Bureau of Indian Standards, IS 1893: (Part 1) 2002) as shown in figure 1. According to the modified Mercalli intensity scale, the seismic zones are classified as zone II (low-intensity zone), zone III (moderate-intensity zone), zone IV (high-intensity zone) and zone V (very-highintensity zone). Zone $\mathrm{V}$ includes mainly parts of Uttarakhand (Alaknanda valley), Jammu and Kashmir, Himachal Pradesh and North Bihar, in addition to the entire north-east India, Rann of Kutch in Gujarat and the Andaman and Nicobar Islands.

The Tapovan Vishnugad Hydropower Project (TVHPP) of $520 \mathrm{MW}$ in Uttarakhand is a 'Run off the River Scheme' on the Dhauli-Ganga. The Powerhouse Complex, located on the left bank of the Alaknanda river, consists of a number of underground excavations such as machine hall or powerhouse chamber, transformer hall, bus ducts, adit to pressure shaft (APS), cable ventilation tunnel (CVT), pen stocks, etc. The powerhouse is at $300 \mathrm{~m}$ depth at the junction of middle-higher Himalayan belt. It is very close to the north of the main central thrust (MCT) - a low-angle northern dipping tectonic plate (Geological Survey of India 2000) and is constructed within a heavily stressed rock mass. During the excavation of the powerhouse, a number of incidences of rockburst occurred. Excavation

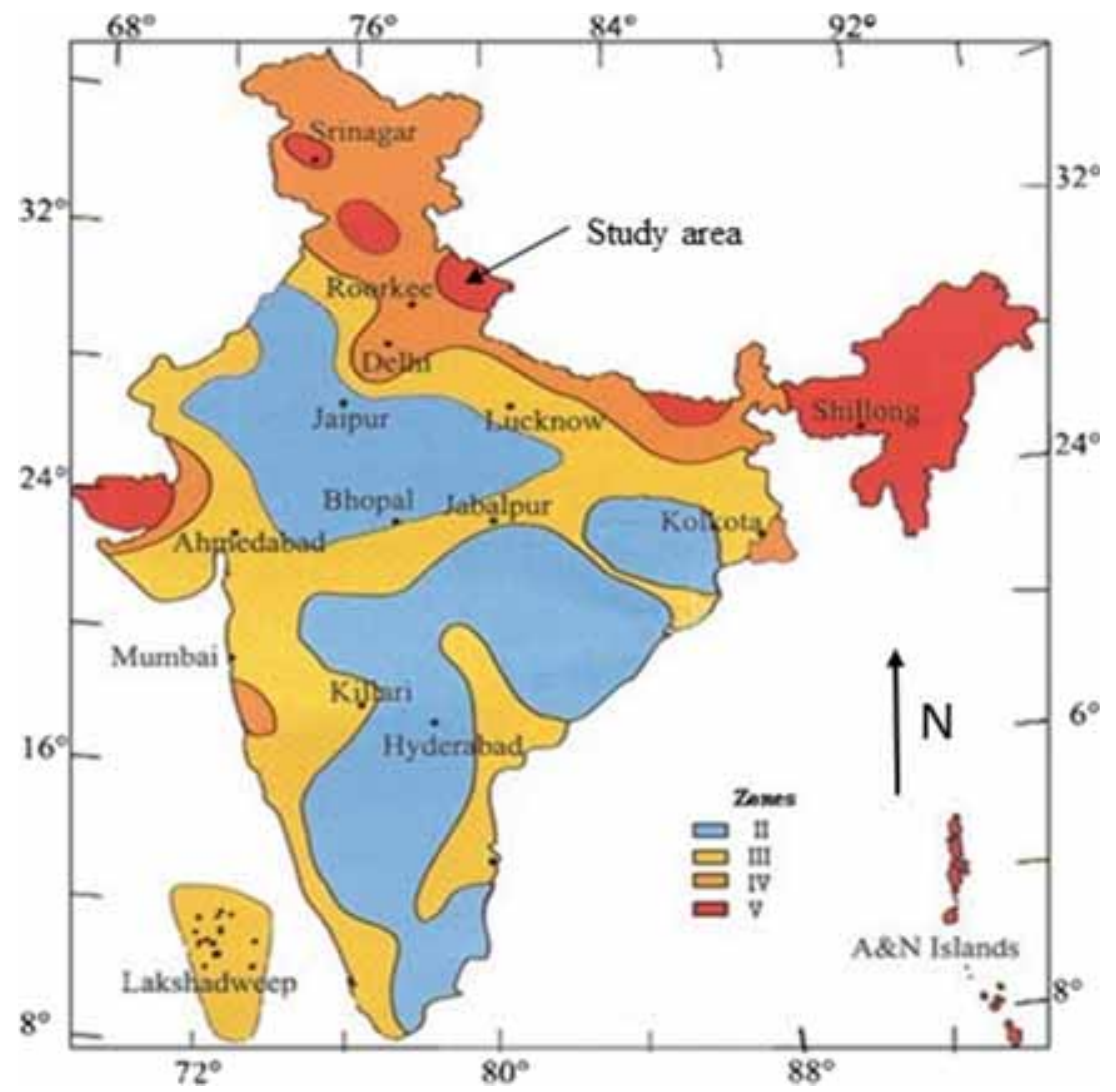

Figure 1. Seismic zonation map (Bureau of Indian Standards, IS 1893: (Part 1) 2002). 
in rock mass increases the stress levels around the openings of caverns, thereby increasing the threat of instability to the underground structure. In view of the safety of the working personnel, a number of studies have been attempted to monitor and predict the rockbursts in the rocks surrounding the powerhouse complex of TVHPP but none of these methods provide information about the dynamic movement in the rockmass along with the real-time and remote monitoring capability. Therefore, it is necessitated to continuously monitor the convergence of the walls, stress level in different areas, displacements at various depths and the load on the supporting structures that results in the installation of the multi-station microseismic monitoring system in the cavern of the TVHPP powerhouse to identify the high-stress zones, record the crack initiation and its propagation in the rock in and around the powerhouse cavern to take precautionary steps in advance (Nuwen et al. 2012). The microseismic monitoring system, manufactured and supplied by the Institute of Mine Seismology, Australia was installed in the powerhouse complex of TVHPP in 2013 to understand the complete strata behaviour after excavation. This paper discusses the conventional instruments limitation, project description, microseismic monitoring networking and preliminary investigation of the stability of the powerhouse in and around the APS, four unit penstocks and upstream wall of the powerhouse chamber.

\section{Limitations of conventional instruments to assess the stability of the excavations}

Typically, there are two ways in which the excavated TVHPP powerhouse can be considered unstable: (i) it appears to be stable but the excavation results in variations of the stress pattern or (ii) earlier signature of excessive stress may appear in the form of cracks, fractures, faults, joints or other signs of rock movement. So, there is a need to identify the areas of temporal and spatial variation of micro-cracks which may lead to the failure of cavern rock mass.

Several studies with the classical monitoring equipment such as load cell, extensometer, MPBX, etc., have been made to analyse the stability of different caverns of powerhouse and the behaviour of the surrounding rock mass during and after excavation. The classical monitoring equipments analyse stability in only one or two dimensions of the powerhouse but they are devised to study the current loading system in three dimensions for better understanding of the behaviour of the structure post excavation. Different conventional instruments (load cells, piezometers, extensometers, MPBX, etc.) are used to study the rock mass behaviour in terms of displacement and stress at the TVHPP powerhouse. But the major limitations of these instruments are: limited number of data points, non-functioning of many equipments after excavation because the damaged equipments are generally not replaced in time, manual recording of the readings and off-line data analysis, inaccessibility of some of the instruments installed at locations, the instruments sometimes might not have been installed in the expected rockburst area and the instruments cannot record dynamic strata behaviour.

The microseismic method of detecting instability and high-stress zones in the rock structure is based on the fact that as a rock mass is subjected to load, small-scale displacements occur within the rock mass which result in the release of seismic and sometimes acoustic energy. These small vibrations, which can be detected with sensitive geophysical equipment, are called microseisms or self-generated rock noises (Wilson et al. 1974). Microseismic events are caused due to the change of stress distribution or the piling of volume of rock mass excavated due to manmade action such as mining and excavation.

Microseismic monitoring is based on the principle that the occurrence of any rock mass failure in the rock mass is not a random process, but it follows a precursory fracture or micro-cracks pattern. Therefore, a study of precursory signatures of micro-cracking and popping inside the rock is a key factor that is not possible by conventional instruments. On the other hand, the microseismic network can record the dynamic data, and the data collected can be analysed in near real time.

The main objective of using microseismic monitoring at TVHPP is to identify: (i) whether the excavated structure is stable or unstable, (ii) to indicate why the powerhouse is becoming unstable and (iii) to assess the magnitude of displacement, stress and other quantitative seismic parameters in the affected areas. With the view of attaining these objectives, the microseismic monitoring technique is used in the area and this will be useful to study the pattern of micro-cracks to predict probable rockburst. 


\section{Project description}

\subsection{Description of the powerhouse complex}

The powerhouse complex of TVHPP located on the left bank of the Alaknanda river consists of a number of underground excavations such as powerhouse chamber, transformer hall, escape tunnel, bus ducts, connecting tunnel, CVT, pen stocks, APS and other minor excavations.

The layout of the powerhouse is shown in figure 2 along with the dimensions of the powerhouse chamber, transformer hall and other major excavations in table 1. Two bus ducts, connecting tunnel and escape tunnel which are separating the powerhouse chamber to the transformer hall are D shaped.
The powerhouse and transformer hall are separated by a pillar of $55 \mathrm{~m}$ thickness. The caverns have been excavated by the conventional drill and blast method.

\subsection{Geology of TVHPP powerhouse complex}

Figure 3 shows the litho-tectonic map of the Alaknanda basin (Célérier et al. 2009) in which the TVHPP powerhouse is located. MCT is at a distance of approximately $2.0 \mathrm{~km}$ southwest and downstream of the powerhouse complex. The major shear seam and shear zone of the TVHPP powerhouse complex is shown in figure 4. The powerhouse area located in the Alaknanda valley is situated within rocks grouped as the Central

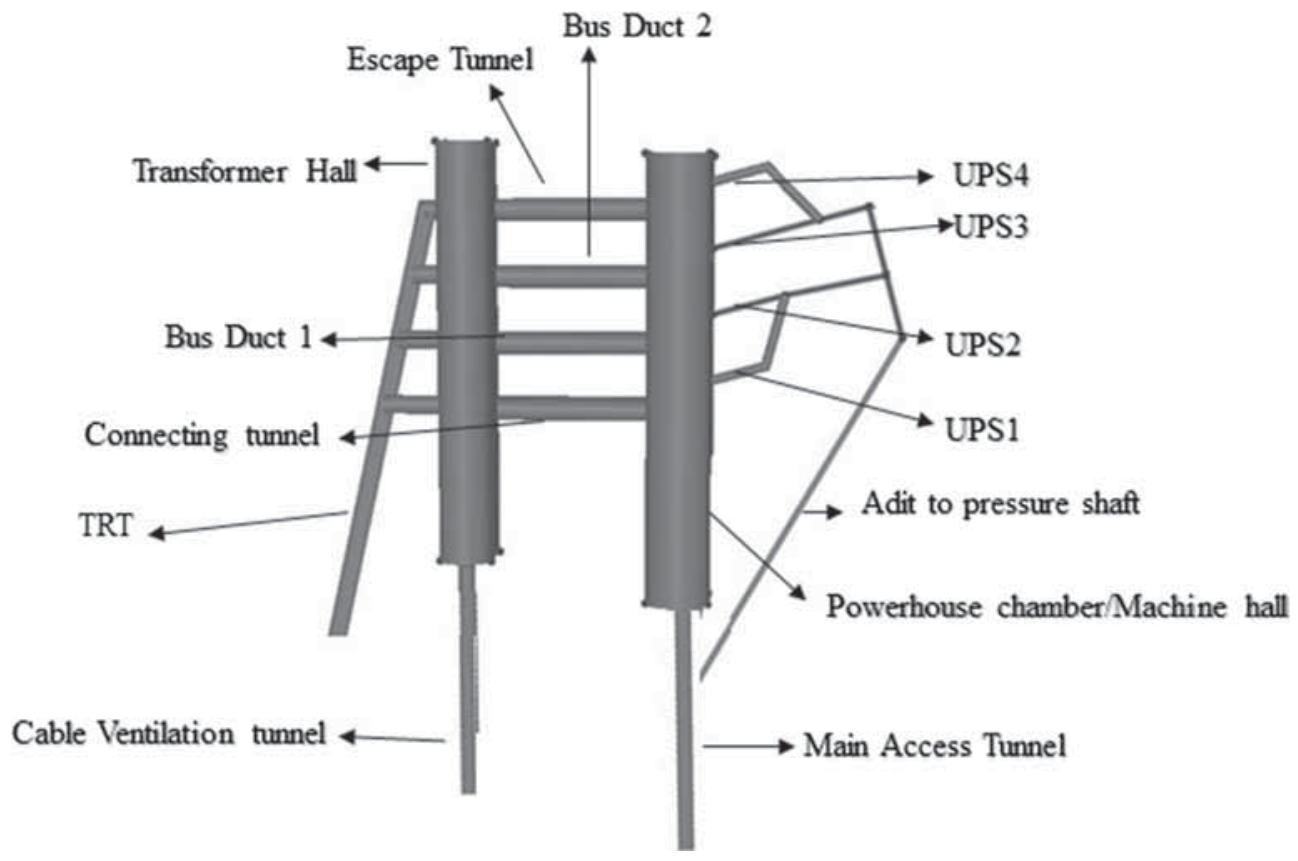

Figure 2. TVHPP powerhouse layout.

Table 1. Excavation dimensions in the powerhouse.

\begin{tabular}{rlcccc}
\hline $\begin{array}{l}\text { Sl. } \\
\text { no. }\end{array}$ & \multicolumn{1}{c}{ Tunnel } & $\begin{array}{c}\text { Length } \\
(\mathrm{m})\end{array}$ & $\begin{array}{c}\text { Width } \\
(\mathrm{m})\end{array}$ & $\begin{array}{c}\text { Crown EL } \\
(\mathrm{m})\end{array}$ & $\begin{array}{c}\text { Floor EL } \\
(\mathrm{m})\end{array}$ \\
\hline 1 & Powerhouse chamber & 158.50 & 22.30 & 1314.87 & 1289.00 \\
2 & Transformer hall & 147.75 & 18.00 & 1316.65 & 1289.00 \\
3 & Escape tunnel & 55.00 & 3.0 & 1292.00 & 1289.00 \\
4 & Bus duct 1 and 2 & 55.00 & 12.0 & 1285.5 & 1297.00 \\
5 & Connecting tunnel & 55.00 & 8.0 & 1289.0 & 1297.00 \\
6 & CVT & 289.21 & 6.0 & 1306.0 & 1300.00 \\
7 & Main access tunnel & 294.00 & 8.0 & 1306.0 & 1300.00 \\
8 & APS & 245.10 & 6.0 & 1281.55 & 1273.55 \\
9 & Unit pen stock 1 and 4 & 45.81 & 6.0 & 1281.05 & 1273.55 \\
10 & Unit pen stock 2 & 27.33 & 6.0 & 1281.05 & 1273.55 \\
11 & Unit pen stock 3 & 39.76 & 6.0 & 1281.05 & 1273.55 \\
12 & Tail race tunnel (TRT) & 355.00 & 7.0 & 1267.5 & 1274.00
\end{tabular}




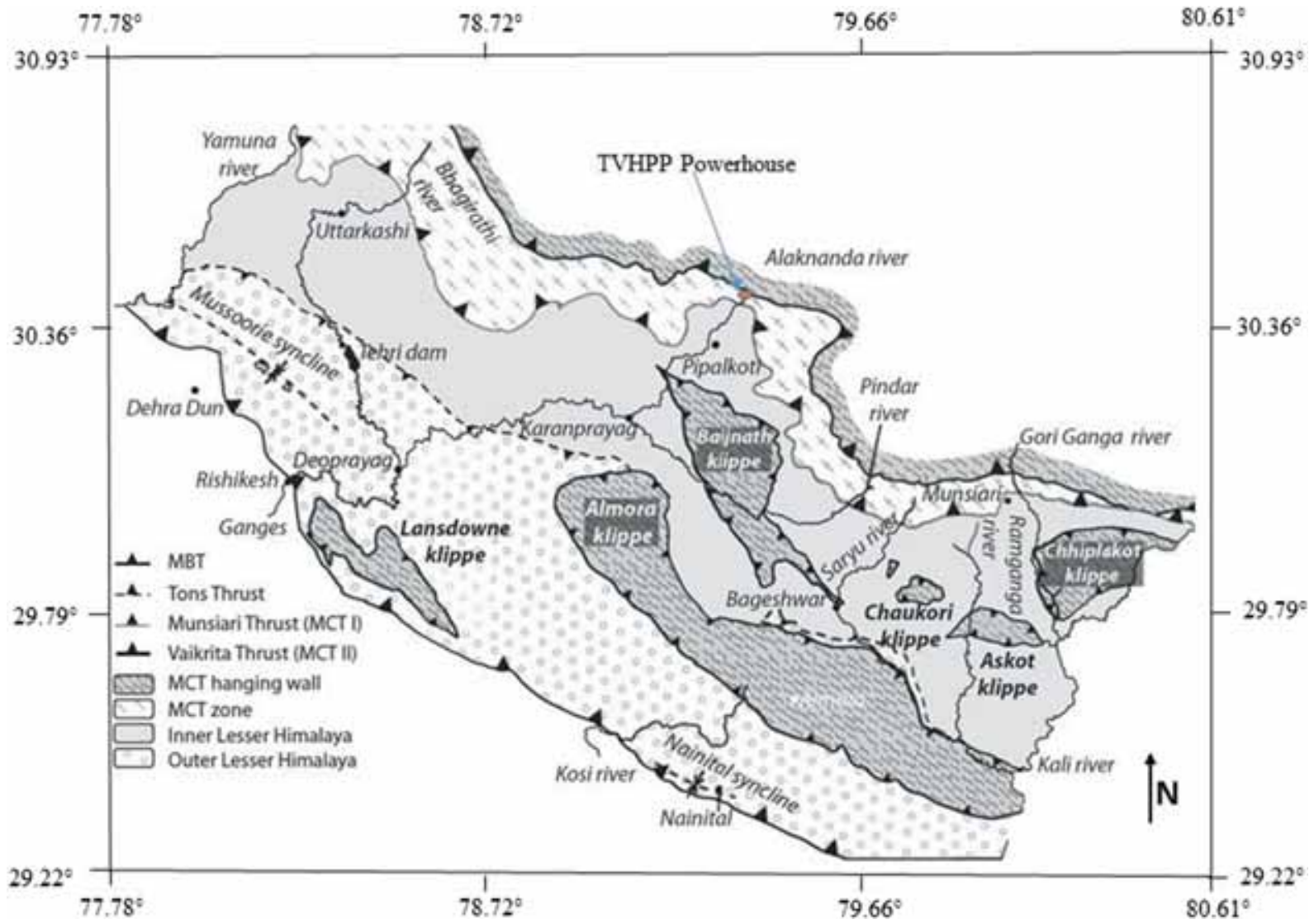

Figure 3. Lithotectonic map of the Alaknanda basin (Célérier et al. 2009).

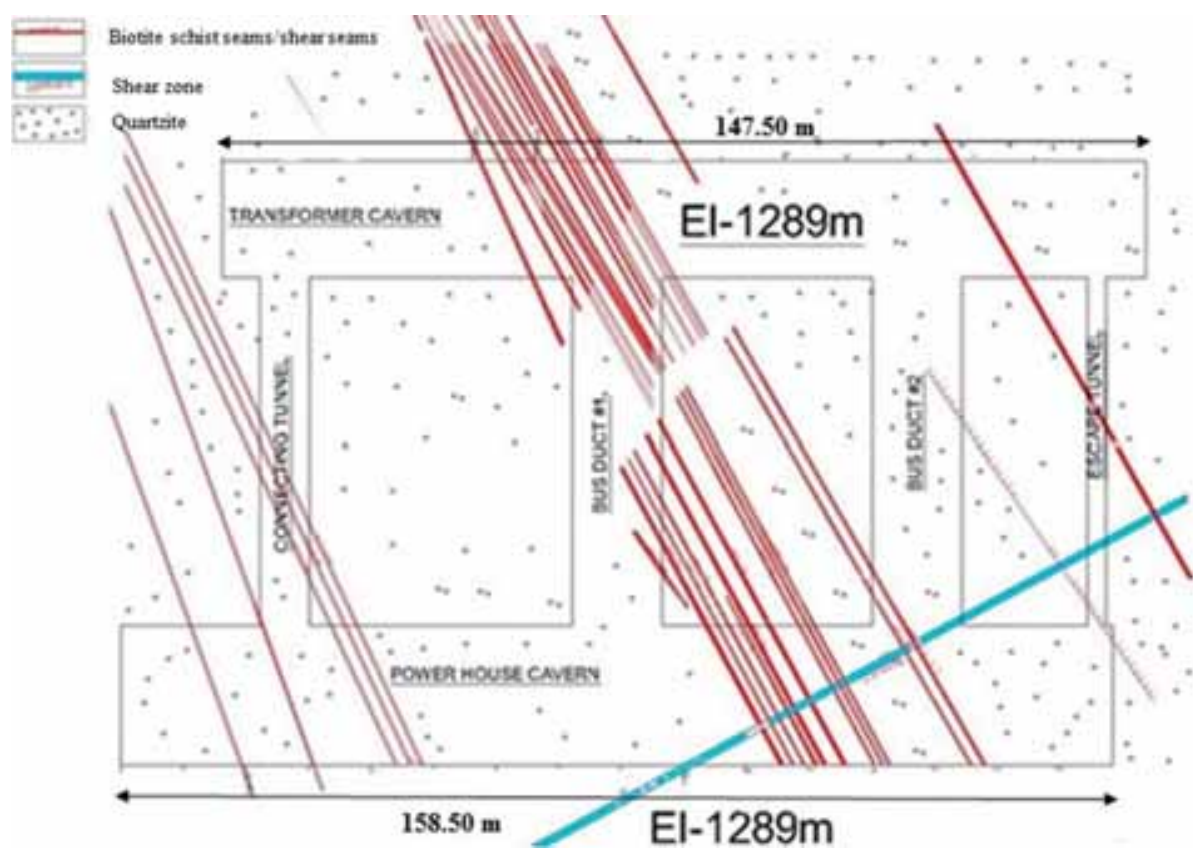

Figure 4. Shear seam and shear zone observed in the powerhouse.

Himalayan crystalline rocks, composed mainly of medium- to high-grade metamorphic rocks. The crystalline rocks of the Dhauli-Ganga valley are derived from pelitic, semi-pelitic and psammitic sediments which occasionally are interlayered with metabasics. In the Dhak Jharkula area, calcareous rocks are also recognised to a lesser extent. 
Towards the south, the crystallines are thrust over the lesser Himalayan sediments of the Garhwal Group of rocks along the MCT. This passes through the Helang village located $2 \mathrm{~km}$ downstream of the proposed powerhouse site area. The rocks of this area can be classified into two formations, namely, Tapovan and Joshimath formations. In between the Tapovan and Joshimath formations, there is no shear plane or topographical break. The rocks exhibit a progressive northward increase in grades of metamorphism and a well-marked continuity of different tectonic elements.

The area of the powerhouse is bounded by a ridge and stream to the north of the Shelang village and Animath nala on the southern side, on the left bank of the Alaknanda. The area exposes mica schists, quartzite, fine-grained quartz mica gneisses and augen gneisses belonging to the Helang formation of the Central Crystalline. These rocks form prominent ridges in the area. The Animath nala ridge, consisting of quartzite, extends from the Shelang village, exposes quartz mica gneisses with schist bands; the valley portion in between is occupied by debris; mica schist is exposed at a higher level near the road level of the Joshimath-Helang. The slope below the Animath ridge is occupied mostly by mica schist with quartz veins.

Table 2. Prominent joint sets.

\begin{tabular}{llcc}
\hline $\begin{array}{l}\text { Joint } \\
\text { set }\end{array}$ & \multicolumn{1}{c}{ Attitude } & Spacing & Remarks* \\
\hline S1 & N70-80 ${ }^{\circ} \mathrm{W}-\mathrm{S} 70-80 \mathrm{E}$ & $10-50 \mathrm{~cm}$ & $\mathrm{PR}$ \\
$\mathrm{S} 2$ & $\mathrm{NW}-\mathrm{SE} / 20-50 / \mathrm{SW}$ & $20-50 \mathrm{~cm}$ & $\mathrm{PR}$ \\
$\mathrm{S} 3$ & $\mathrm{NNE}-\mathrm{SSW} /$ vertical & $50-150 \mathrm{~cm}$ & $\mathrm{RU}$ \\
\hline
\end{tabular}

*PR: planar/rough; RU: rough/undulating.
The rock mass in the area has a foliation trend varying from $\mathrm{N} 70^{\circ} \mathrm{W}-\mathrm{S} 70^{\circ} \mathrm{E}$ to $\mathrm{NW}-\mathrm{SE}$ with dips of $40-60^{\circ}$ towards the NE. The detailed study of the quartzite along the road section above the powerhouse drift has indicated that the quartzite is of three types i.e., massive, jointed and highly jointed types, based on the joints and their spacing. The quartzitic rocks generally strike $\mathrm{N} 70^{\circ} \mathrm{W}-\mathrm{S} 70^{\circ} \mathrm{E}$ and dip at $30-40^{\circ}$ towards $\mathrm{N} 20^{\circ} \mathrm{E}$ direction. The prominent joint sets recorded in the quartzite are shown in table 2.

A shear zone (1 $\mathrm{m}$ thick with a $10 \mathrm{~cm}$ gouge) passes in the zone of the crown of the powerhouse. Besides the shear zone, there exist bands of biotite schist seams (10-15 cm thick) along the foliation joint (J1) cutting both the powerhouse (between 75 and $110 \mathrm{~m}$ chainage) and the transformer hall (between 14 and $33 \mathrm{~m}$ chainage). The rock discontinuity characteristics along the powerhouse cavern are given in table 2 . It can be noticed that three distinct discontinuities, namely, S1, S2 and S3 of varying orientation exist along the powerhouse.

\section{Microseismic monitoring for post-excavation of powerhouse structure}

In underground TVHPP powerhouse structure, excavation of an enormous volume of rock for a longer cavern depth causes stress redistribution. The stress redistribution may start fracture initiation, rock mass movement and other processes and such processes generally radiate seismic energy. Hence, excavation induced seismicity can be defined as the rock mass response due to deformation.

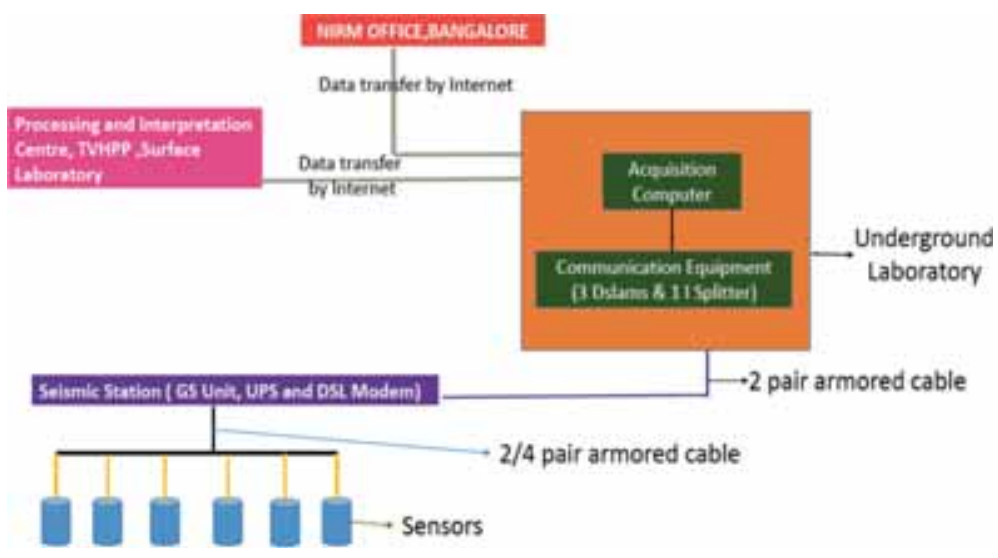

Figure 5. Microseismic monitoring system layout at TVHPP. 


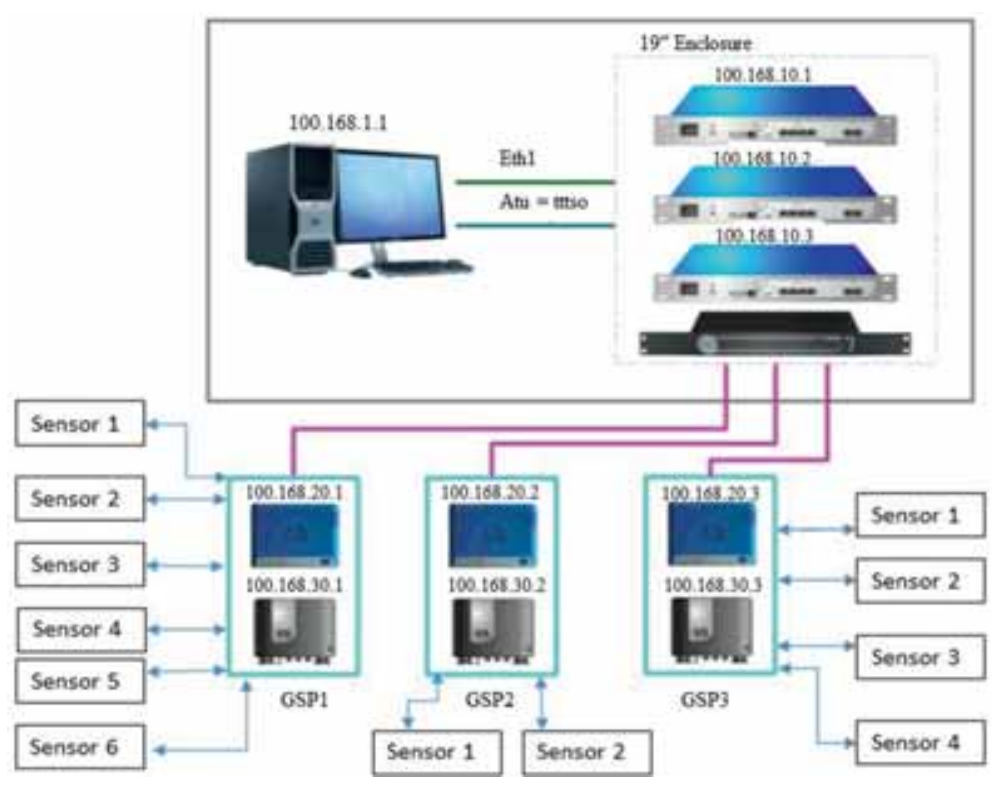

Figure 6. Constituents of TVHPP microseismic monitoring system.

The areas inside the powerhouse, particularly the crown and side walls are prone to rockburst which may cause fright and concern among the workforce personnel. Such intrinsic ambiguity associated with the excavated rock cavern of the powerhouse makes it essential to continuously monitor the whole TVHPP powerhouse structure especially the side walls and crown region. The monitoring system will determine the status of stress accumulation zones to indicate the strata behaviour in real time. Therefore, such excavation-induced seismicity can be studied by using the microseismic monitoring method. The microseismic method facilitates the timely assessment of any instability and the identification of high-stress zones in the excavated structure. The source location of the microseismic events will indicate the areas in which fracturing occurs (Essrich 2005).

The microseismic monitoring system outline at TVHPP is shown in figure 5. It consists of sensors, data acquisition units, cable layout, seismological acquisition, processing, analysis and visualisation software. By quantification of the seismic response of the rock mass to the underground excavation of the TVHPP powerhouse structure, one may be able to demarcate the potential failure zones (Mendecki 1997). Continuous data recording in the underground laboratory is being carried out in the acquisition workstation, QC processing, event visualisation and notification in the surface laboratory. The further detailed processing, analysis,

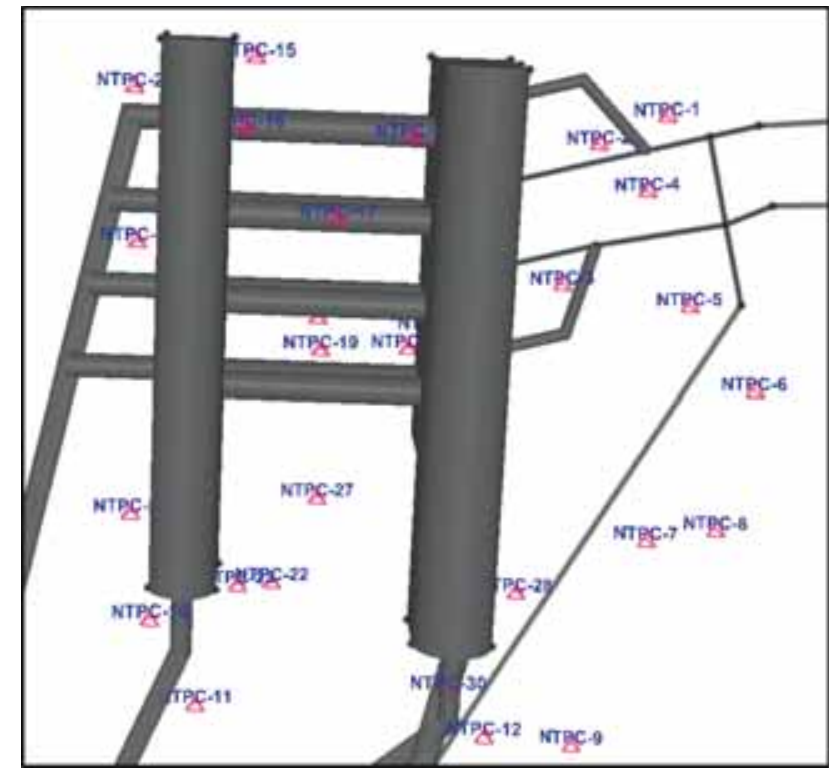

Figure 7. Installed geophone locations on the $3 \mathrm{D}$ view of the powerhouse.

interpretation and visualisation are being performed at the NIRM office, Bengaluru.

\section{Microseismic monitoring equipment network at TVHPP}

The microseismic monitoring network installed at TVHPP (manufactured by the Institute of Mine Seismology, Australia) consists of a desktop 
Table 3. Geophone coordinate with location.

\begin{tabular}{|c|c|c|c|c|}
\hline Sl. & & oordinate $(1$ & & \\
\hline no. & Northing & Easting & Elevation & Location \\
\hline 1 & $35,140.50$ & $20,328.20$ & 1284.11 & Junction of penstock 04 and HPS*02 D/S* \\
\hline 2 & $35,139.50$ & $20,309.80$ & 1269.01 & Junction of penstock 3 and 4 \\
\hline 3 & $35,111.10$ & $20,282.62$ & 1283.94 & Junction of penstock 1 and 2 \\
\hline 4 & $35,123.00$ & $20,315.41$ & 1278.12 & HPS $01 \mathrm{D} / \mathrm{S}$ \\
\hline 5 & $35,089.60$ & $20,311.66$ & 1284.84 & APS L/S* \\
\hline 6 & $35,060.10$ & $20,317.56$ & 1288.21 & APS R/S* \\
\hline 7 & $35,036.24$ & $20,272.05$ & 1293.36 & APS L/S \\
\hline 8 & $35,028.51$ & $20,291.06$ & 1289.52 & APS R/S \\
\hline 9 & $34,992.80$ & $20,227.13$ & 1299.73 & APS L/S \\
\hline 10 & $35,087.70$ & $20,143.14$ & 1321.07 & $\mathrm{TH}$ adit $\mathrm{L} / \mathrm{S}$ \\
\hline 11 & $35,053.80$ & $20,138.16$ & 1302.28 & TH adit and cable shaft junction \\
\hline 12 & $35,014.10$ & $20,207.76$ & 1316.55 & $\mathrm{CVT} \mathrm{R} / \mathrm{S}$ \\
\hline 13 & $35,179.41$ & $20,243.51$ & 1288.85 & Left wall mid of bus duct 2 - escape tunnel side \\
\hline 14 & $35,168.29$ & $20,263.67$ & 1297.13 & Left wall end of bus duct 2 - escape tunnel side \\
\hline 15 & $35,206.10$ & $20,235.80$ & 1295.07 & Junction of transformer hall and escape tunnel \\
\hline 16 & $35,190.92$ & $20,224.78$ & 1296.35 & Entrance bus duct $2-$ towards escape tunnel \\
\hline 17 & $35,158.25$ & $20,235.67$ & 1299.10 & Mid bus duct 2 - towards bus duct 1 wall \\
\hline 18 & $35,134.60$ & $20,218.05$ & 1288.70 & Mid bus duct $1-$ towards bus duct 2 \\
\hline 19 & $35,127.03$ & $20,214.92$ & 1292.71 & Mid bus duct 1 - towards connecting tunnel \\
\hline 20 & $35,117.12$ & $20,245.43$ & 1290.70 & End bus duct $1-$ towards bus duct 2 \\
\hline 21 & $35,114.52$ & $20,236.22$ & 1284.59 & End bus duct 1 - towards connecting tunnel \\
\hline 22 & $35,073.53$ & $20,172.41$ & 1293.25 & Connecting tunnel - towards $\mathrm{TH}$ adit \\
\hline 23 & $35,078.41$ & $20,164.22$ & 1297.5 & Entrance connecting tunnel towards bus duct 1 \\
\hline 24 & $35,110.37$ & $20,147.13$ & 1295.90 & $\begin{array}{l}\mathrm{D} / \mathrm{S} \text { wall transformer hall between and opposite } \\
\text { to the connecting tunnel and bus duct } 1\end{array}$ \\
\hline 25 & $35,213.55$ & $20,202.80$ & 1288.23 & $\begin{array}{l}\text { Downstream wall transformer hall - opposite } \\
\text { to the escape tunnel }\end{array}$ \\
\hline 26 & $35,176.08$ & $20,183.70$ & 1288.76 & $\begin{array}{l}\text { Downstream wall transformer hall between and } \\
\text { opposite to bus duct } 1 \text { and } 2\end{array}$ \\
\hline 27 & $35,088.88$ & $20,194.63$ & 1289.42 & Middle of connecting tunnel - towards bus duct 1 \\
\hline 28 & 35,03910 & $20,232.57$ & 1293.30 & Machine hall upstream wall - in the service bay \\
\hline 29 & $35,145.91$ & $20,199.94$ & 1282.67 & Start of bus duct $1-$ towards bus duct 2 \\
\hline 30 & $35,032.45$ & $20,205.40$ & 1321.01 & Junction of powerhouse chamber and CVT in crown \\
\hline
\end{tabular}

*HPS: high-pressure side; D/S: downstream; L/S: left side and R/S: right side.

run time digital signal processing system, central communication hub, data acquisition unit and geophone (sensor) transducer installed in boreholes drilled in the rock mass in the rock tunnel/crown as shown in figure 6 .

Three-dimensional visualisation of the installed geophone at different locations in the powerhouse is shown in figure 7.

An array of geophones has been designed on the basis of field geological studies, existing cracks in the machine hall, transformer hall, CVT and APS and rockburst history of the site. Sensors in the unit pen stocks have been installed to monitor the forces that have initiated the rockmass movement in the pen stocks. Sensors in the APS have been installed to monitor the activity in the upstream wall of the machine hall. However, due to site constraints only one geophone has been installed in the upstream wall of the machine hall. There exist cracks at the boundary of the machine hall and CVT which will be monitored by the sensors installed in the CVT and the connecting tunnel. The band of biotite schist seam along the foliation joint and the growth of cracks in the bus ducts will be monitored by the sensors installed in the two bus ducts. To monitor the cracks in the end wall of the machine hall, sensors have been installed in the escape tunnel. Rock mass failure may occur in the transformer hall between reduce distance (RD) $25-35$ and $62-67 \mathrm{~m}$. There is a probability 
of rock mass failure between $\mathrm{RD} 10-40 \mathrm{~m}$ as the zone consists of mica-schist and to monitor the cracks in the transformer hall between RD 25 and $72.5 \mathrm{~m}$ at an elevation (EL) of about $1308.0 \mathrm{~m}$, sensors have been installed in the transformer hall at optimum locations. Sensors in the bus ducts have been installed to monitor the propagation of cracks. Table 3 provides the location of different geophones installed in the powerhouse.

A data acquisition unit connects with geophones in three combinations: (i) six uniaxial geophone, (ii) three uniaxial and one triaxial and (iii) two triaxial as shown in figure 3. Geophones are connected to the seismic station (data acquisition unit) using copper twisted-pair cables. The seismic station consists of the geophysical seismometer (GS) unit, intelligent uninterrupted power supply (iUPS) and the digital subscriber line (DSL) modem.

The seismic stations are connected to the central communication hub through a two pair armoured copper cable. Seismic station units rely on a pulse per second signal which originates from the GS unit timing source over the network. This can allow the data from each GS unit to be accurately time-stamped, ensuring that multiple units are in synchronisation. Each GS is a 24-bit device sampled at $48 \mathrm{kHz}$, and achieves time synchronisation using the standard analogue time update mechanism.

The processing system in the desktop run time system (DRTS) performs preliminary event detection when the signal recorded at least four geophones exceed a given threshold, using the short time average $v s$. long time average algorithm. Then DRTS computes in real time a primary hypocentre determination with a homogeneous velocity model for the $\mathrm{P}$ and $\mathrm{S}$ waves and records the data on a hard drive. Finally, the microseismic raw data are then accessed by Team Viewer in the surface laboratory for field processing and real-time event visualisation and notification at the same time to the Department of Microseismics and Engineering Seismology, NIRM, Bengaluru for detailed processing and interpretation.

\section{Primary monitoring results}

The microseismic data during the primary monitoring period for post-excavated powerhouse were

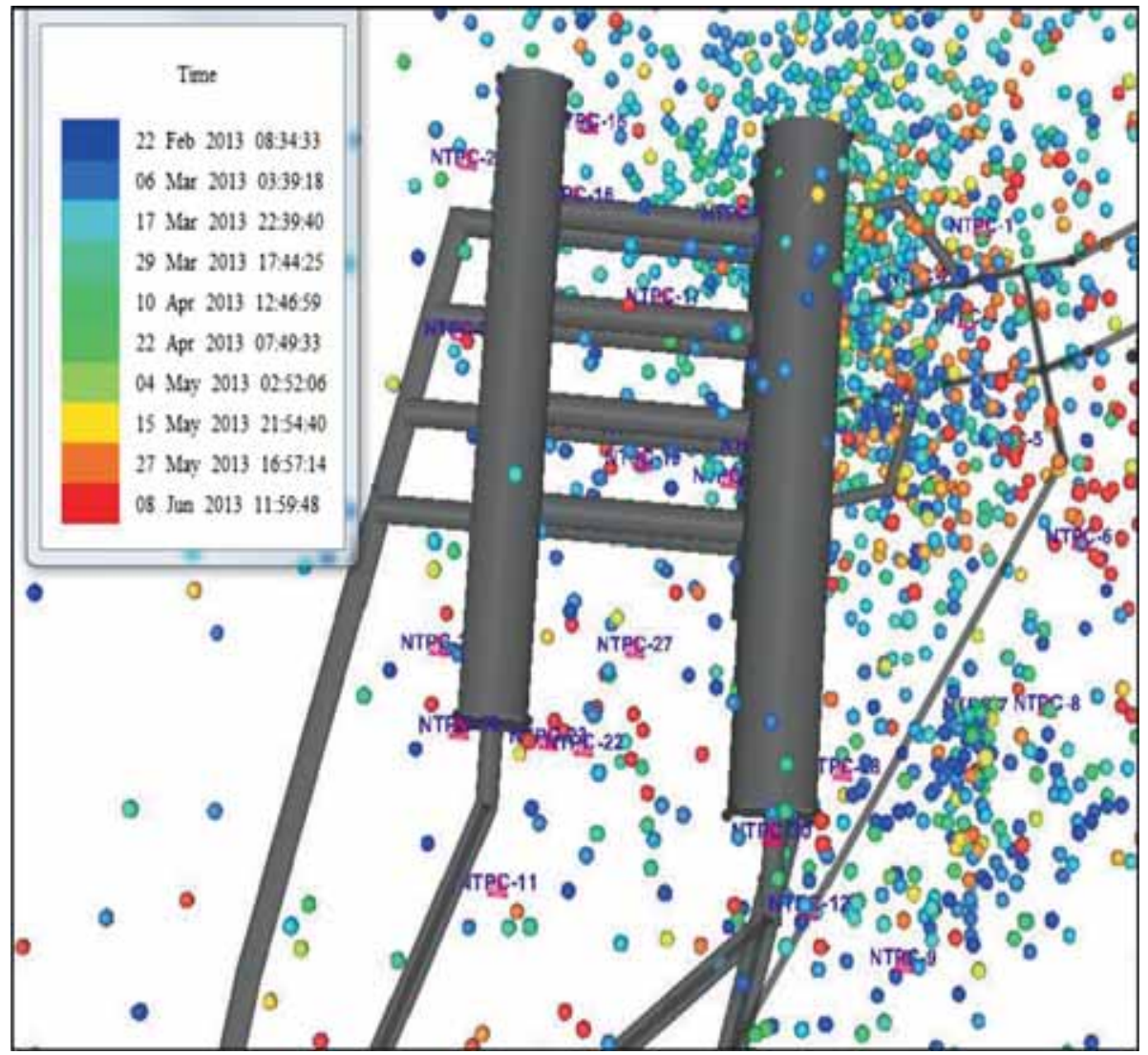

Figure 8. Microseismic events on the 3D cavern plan during the observation period. 


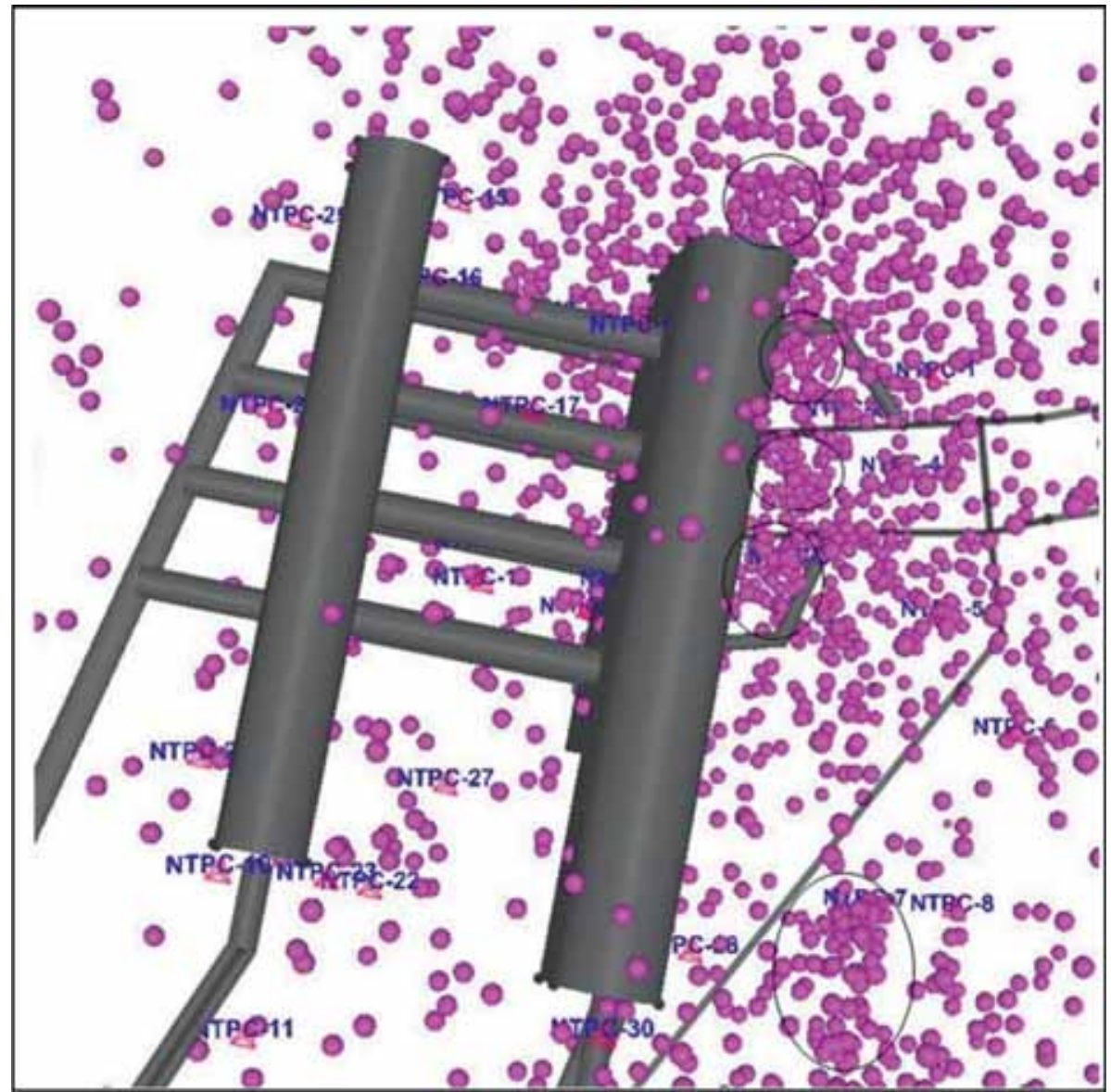

Figure 9. Microseismic event clusters (encircled).

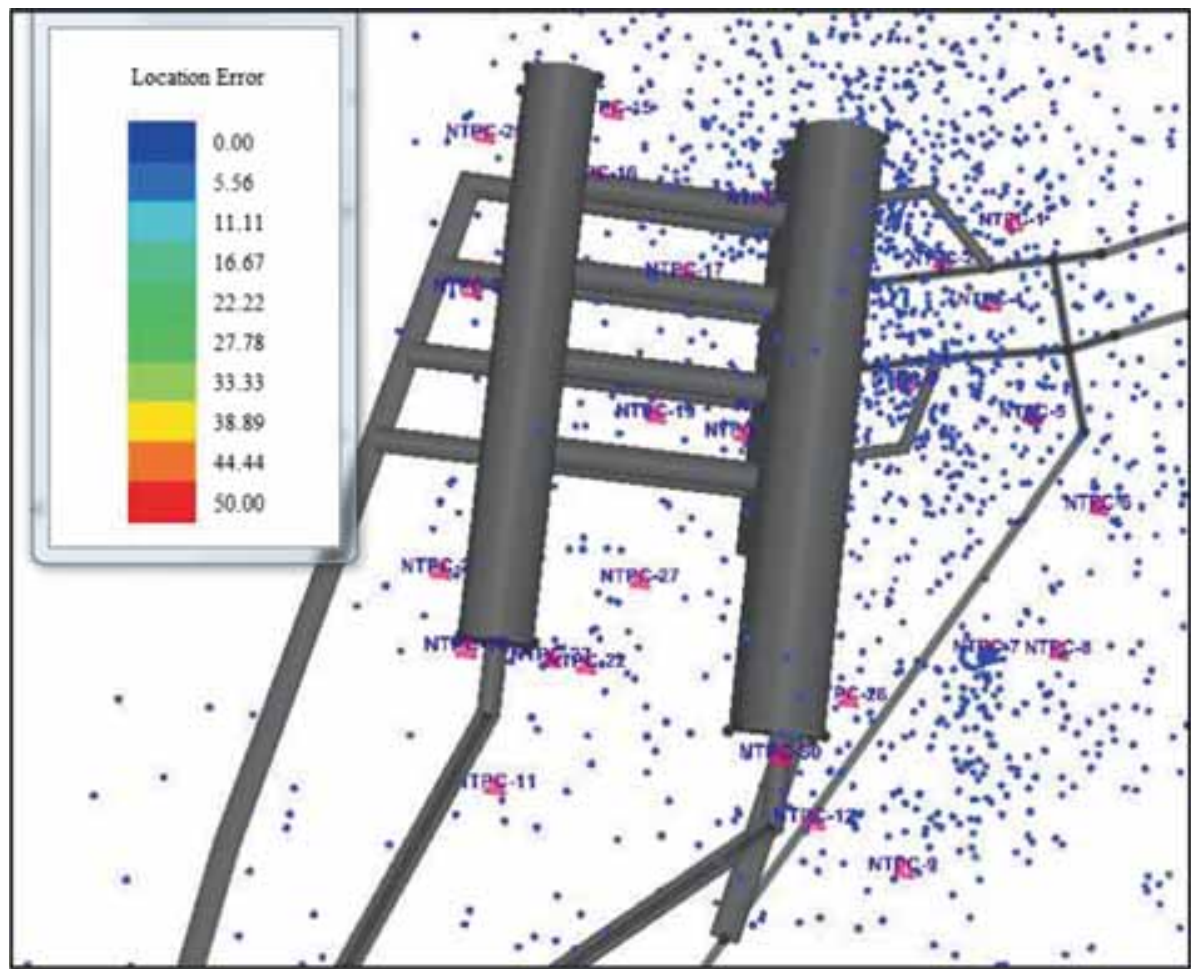

Figure 10. Hypocentral distance (location) error. 
processed only for eight geophones installed in the APS and Unit Pen stocks. The recorded waveform consists of microseismic events, electrical noise, tremors, construction noise and various other types of noise. Out of 15,984 recorded waveforms, only
2254 have been accepted as microseismic events after processing. The microseismic events occurring in and around the powerhouse have high frequency and the travel time difference between the $\mathrm{P}$ and the $\mathrm{S}$ wave is less than $50 \mathrm{~ms}$ while the seismic

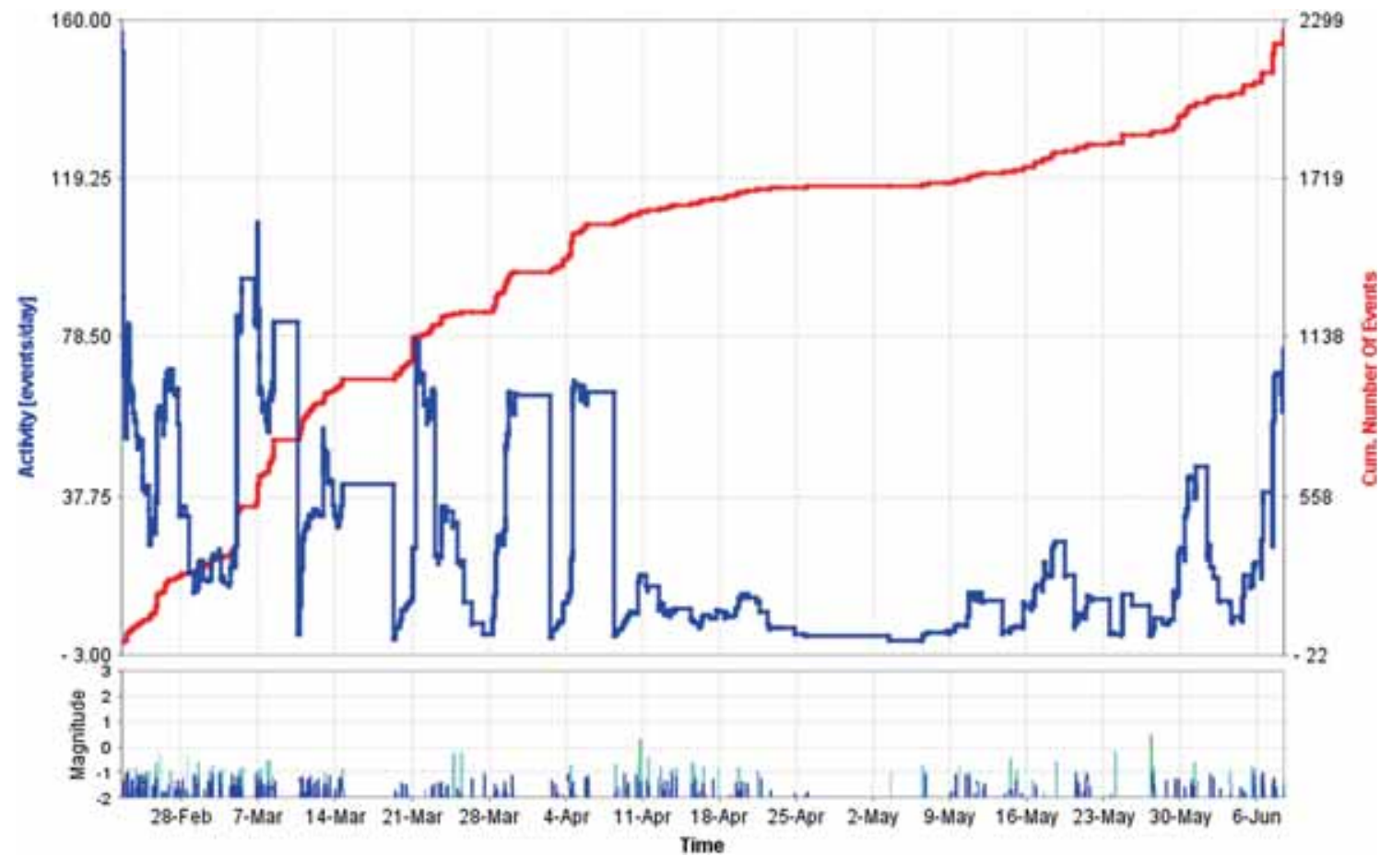

Figure 11. Temporal distribution of microseismic events.

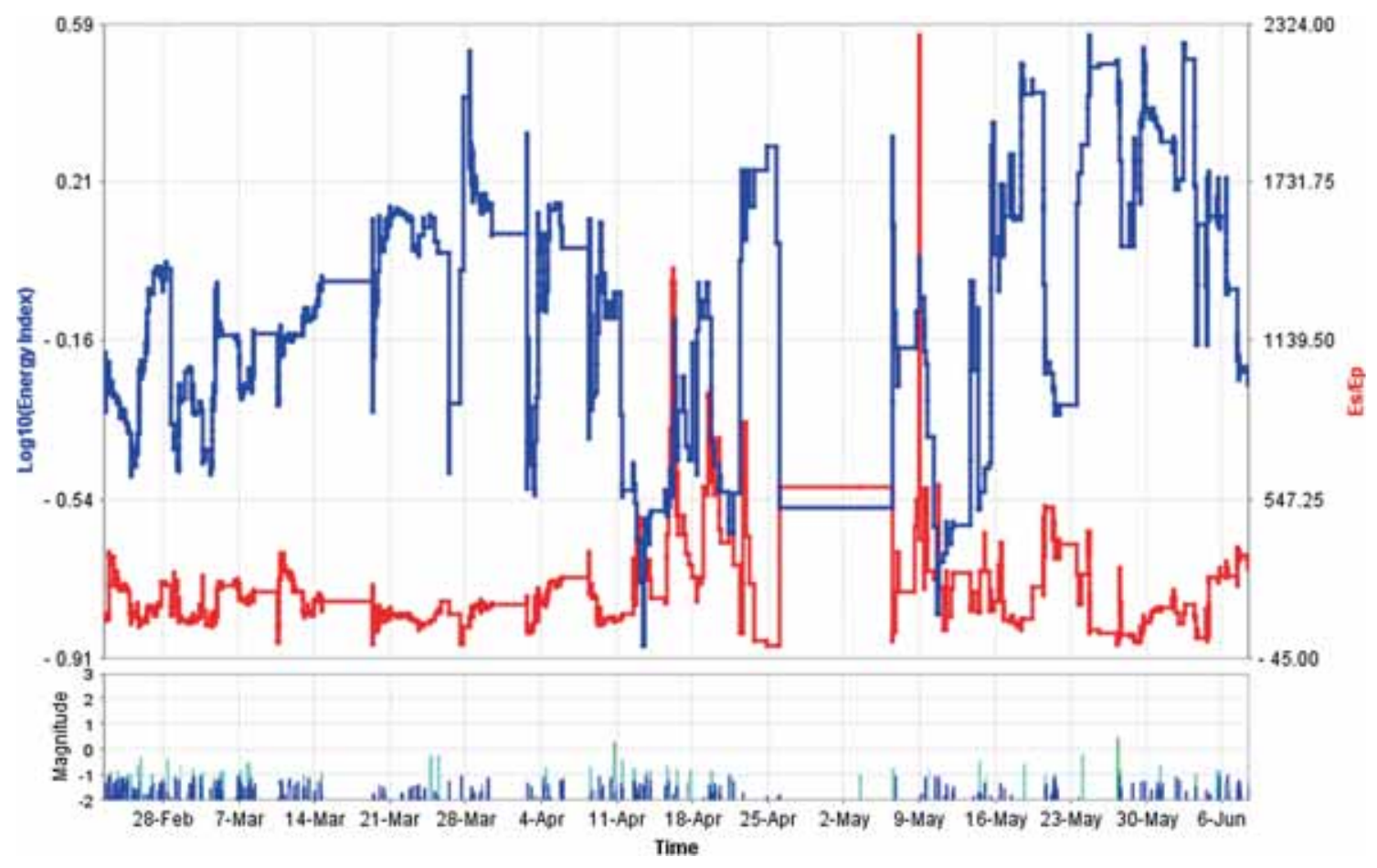

Figure 12. Log energy index vs. $E_{\mathrm{s}} / E_{\mathrm{p}}$. 
tremor recorded by the network has a low frequency and the travel time difference between the $\mathrm{P}$ and the $\mathrm{S}$ wave is more than $1000 \mathrm{~ms}$. The events are mapped on the cavern $3 \mathrm{D}$ plan as shown in figure 8.

Most of the events are in the unit pen stocks, APS and downstream wall of the powerhouse as geophones were initially installed in this zone. Five event concentration clusters are marked in figure 9, which may be potential rock fracture zones in the cavern. The maximum hypocentral location error is about $5.56 \mathrm{~m}$ inside the powerhouse and the error per cent of the average hypocentral distance is 3.5 as shown in figure 10. This equipment is used mainly to evaluate the stability of the powerhouse cavern.

\subsection{Temporal variation of microseismic events}

The microseismic data were analysed for the temporal variations of the different seismic parameters (Chun'an et al. 2010; Ma et al. 2015). Figure 11

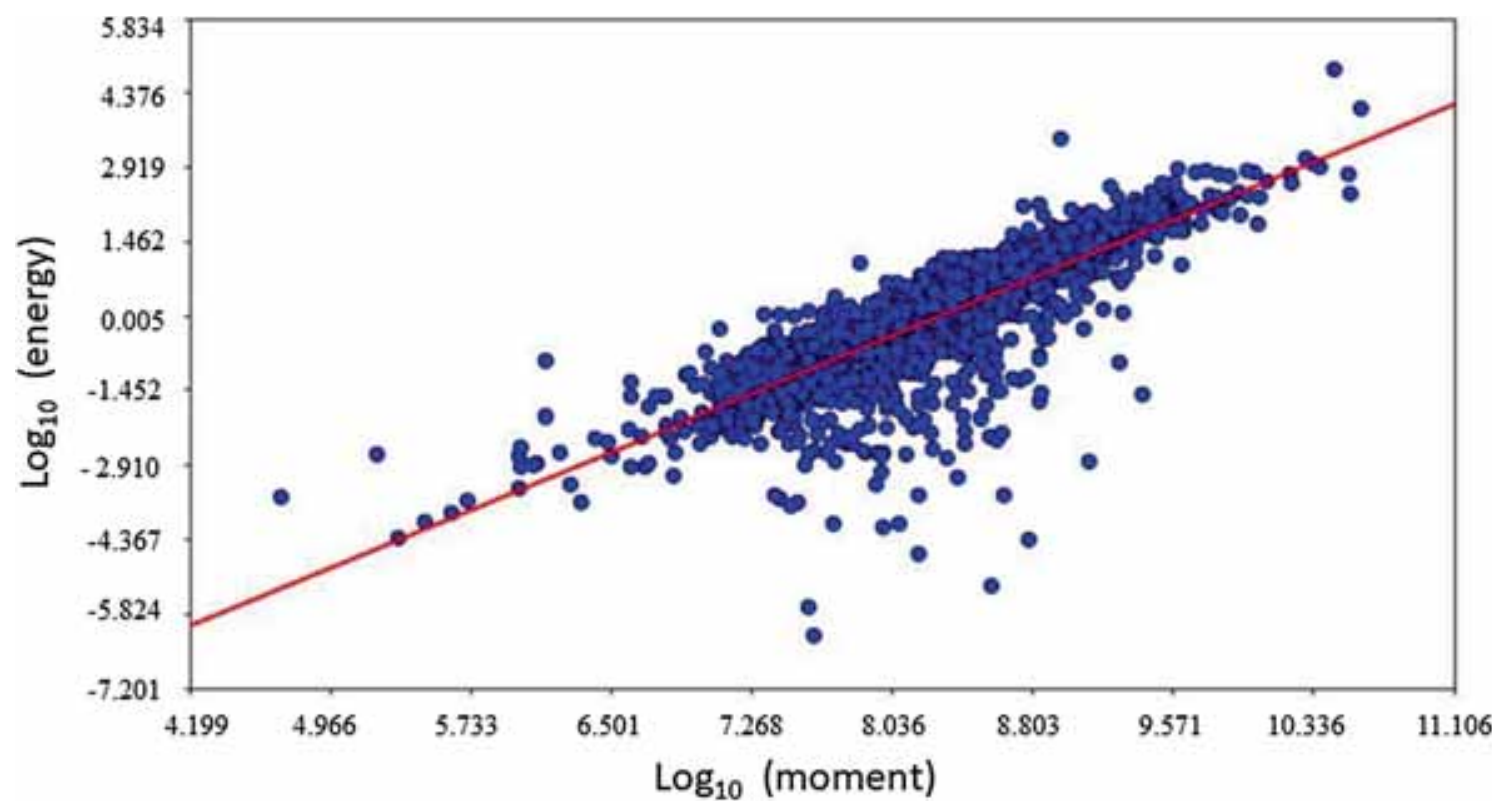

Figure 13. Log (energy) vs. log (moment).

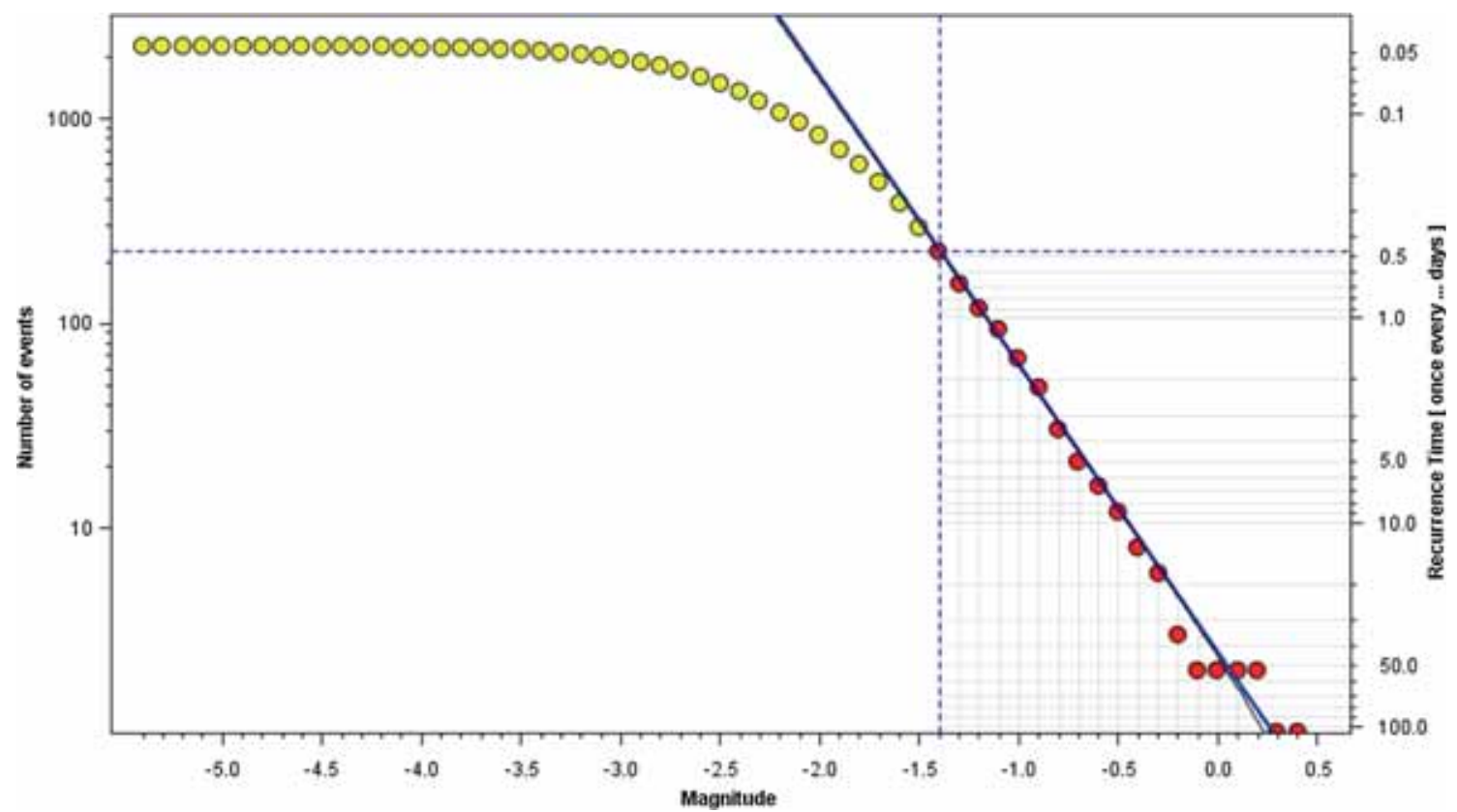

Figure 14. Gutenberg-Richter curve. 
shows the frequency of the activity of microseismic events and the cumulative number of events. From 22 February 2013 to 8 June 2013, the microseismic events occurred except during the period between 27 April-2 May and 4-5 May 2013 due to site constraints. The variation of the energy index and along with the variation in the ratio of the energy of the $\mathrm{S}$ wave to the $\mathrm{P}$ wave is shown in figure 12 .

The variation of energy with the seismic moment for the TVHPP is shown in figure 13. The major portion of $\log _{10}(E)$ varies between -1.99 and 1.91 which indicates that the energy varies between $10 \mathrm{~mJ}$ and $82 \mathrm{~J}$. The logarithmic curve of the seismic energy vs. the moment is a straight line. The slope value is 1.48 and the intercept is -12.27 . The major portion of log (moment) varies between 7.1 and 9.69 which states that the moment varies between $12.97 \times 10^{6}$ and $49.94 \times 10^{8} \mathrm{~N} \mathrm{~m}$.

Micro-cracks in the excavated rockmass occur much more often than earthquakes. This follows a power distribution law as shown in figure 14 called the Gutenberg-Richter law and is described by $\log _{10} N=a-b M$, where $N$ is the cumulative number of events with magnitudes equal to or greater than $M$ and $a$ is the number of events for $M=0$. The variable $b$ describes the relationship between the number of large and small events and is the slope of the line between the number of events and the magnitude. The values of $a$ and $b$ are 0.39 and 1.41 , respectively. The value of $b$ is generally 1 but here the value of $b$ is higher than 1 . In microseismics, since the magnitude is generally less than 0 , so an increase in $b$ value will significantly increase the number of micro-cracks and fractures in the rockmass. As the value of the magnitude drops by 1.41, there is an increase of 10 times in the number of events. If the orientation of any local fault or weak rockmass is favourable for slip under the present stress conditions, the fracture or cracks growing may reactivate the fault or more cracks in the weak rockmass may result in failure. In normal seismology, the higher the value of $a$, the higher the productivity, but in microseismics which generally deals in negative magnitude, the lower the value of $a$, the higher the productivity. Since the value of $a$

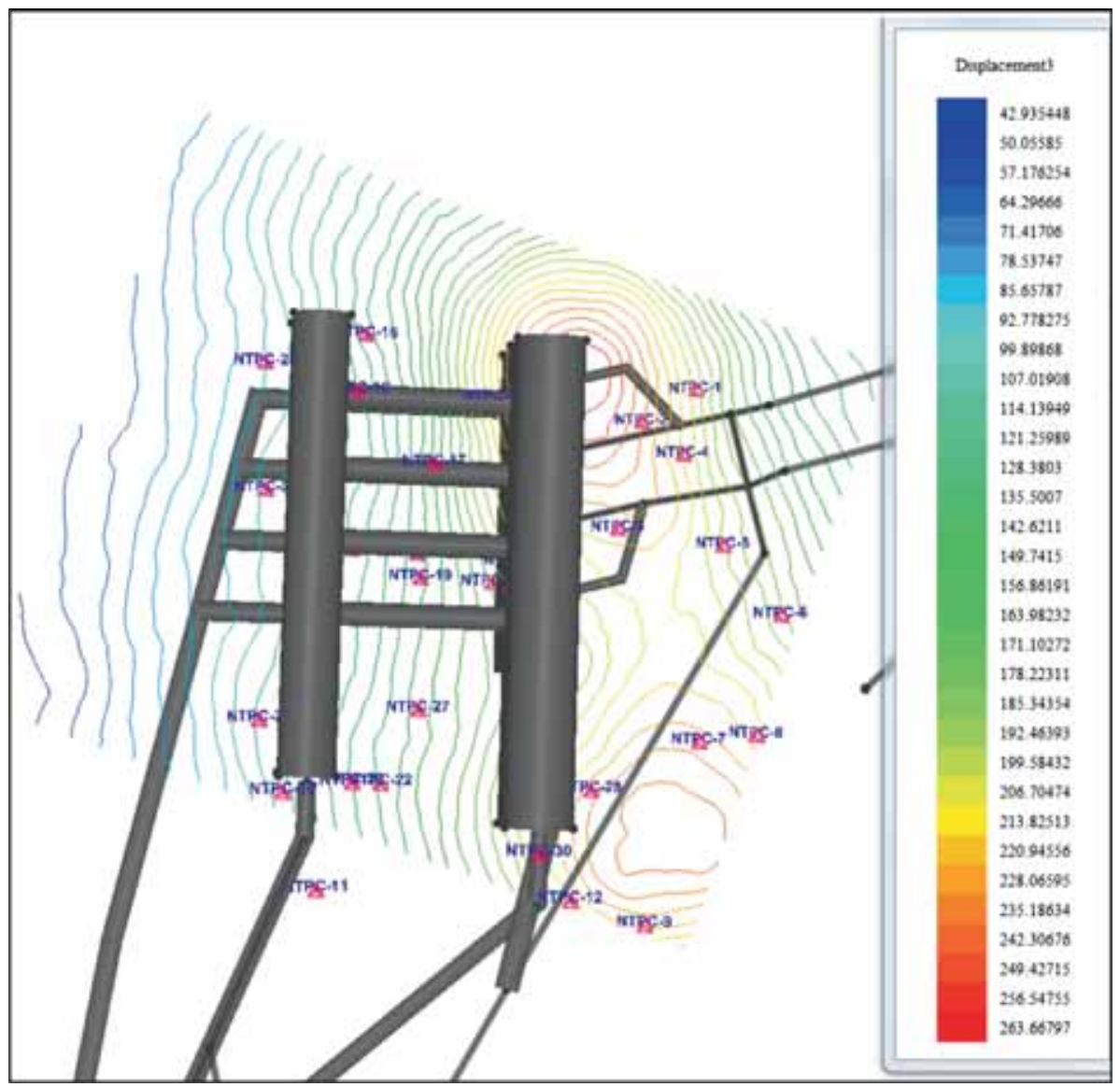

Figure 15. Displacement contour. 
is 0.45 , it indicates that the productivity is more of the micro-cracks in the powerhouse. This relation also provides significant information regarding the recurrence of microseismic events of a certain magnitude. The probability of recurrence of microseismic events of local magnitude of -1.1 and -0.1 are 15 and 90 days, respectively.

\subsection{Spatial variation of microseismic events}

The variation of displacement in different zones of the powerhouse due to the micro-cracks is shown in figure 15. The maximum displacement is around the pen stocks, end of machine hall and in the middle of the APS.

From the spatial variation of events and displacement contour as shown in figures 8 and 15 , respectively, the cluster of events and high displacement are in and around the pen stocks and the middle of the APS. Figure 4 provides information of the shear seam and shear zone of the powerhouse. A cluster of events occurred in and around the cross-section of the shear zone with the biotite schist seam/shear seam.
When apparent stress variations in the powerhouse as shown in figure 16 are compared with figure 15 , there are variations in the area of maximum apparent stress in comparison with the maximum displacement. The rock at the extreme end of the powerhouse chamber may be more under stress in comparison with the rock in the unit pen stocks. But significantly, there is no high apparent stress in those areas where a cluster of events occurred. No rockburst occurred during the monitoring period as the intersection of the shear and seam zone releases energy continuously.

Figure 17 shows the cumulative apparent volume contour having maximum cumulative radius in the APS. This area also has a high number of events which may have resulted in high cumulative apparent volume.

The present status of strata after preliminary analysis indicates that the powerhouse structure appears to be stable (Feng et al. 2015) because the apparent stress is not significantly high enough to cause rockmass failure although the displacement is high in two zones, it is required to monitor the excavated structure for a longer time period to analyse the redistribution pattern of stress.

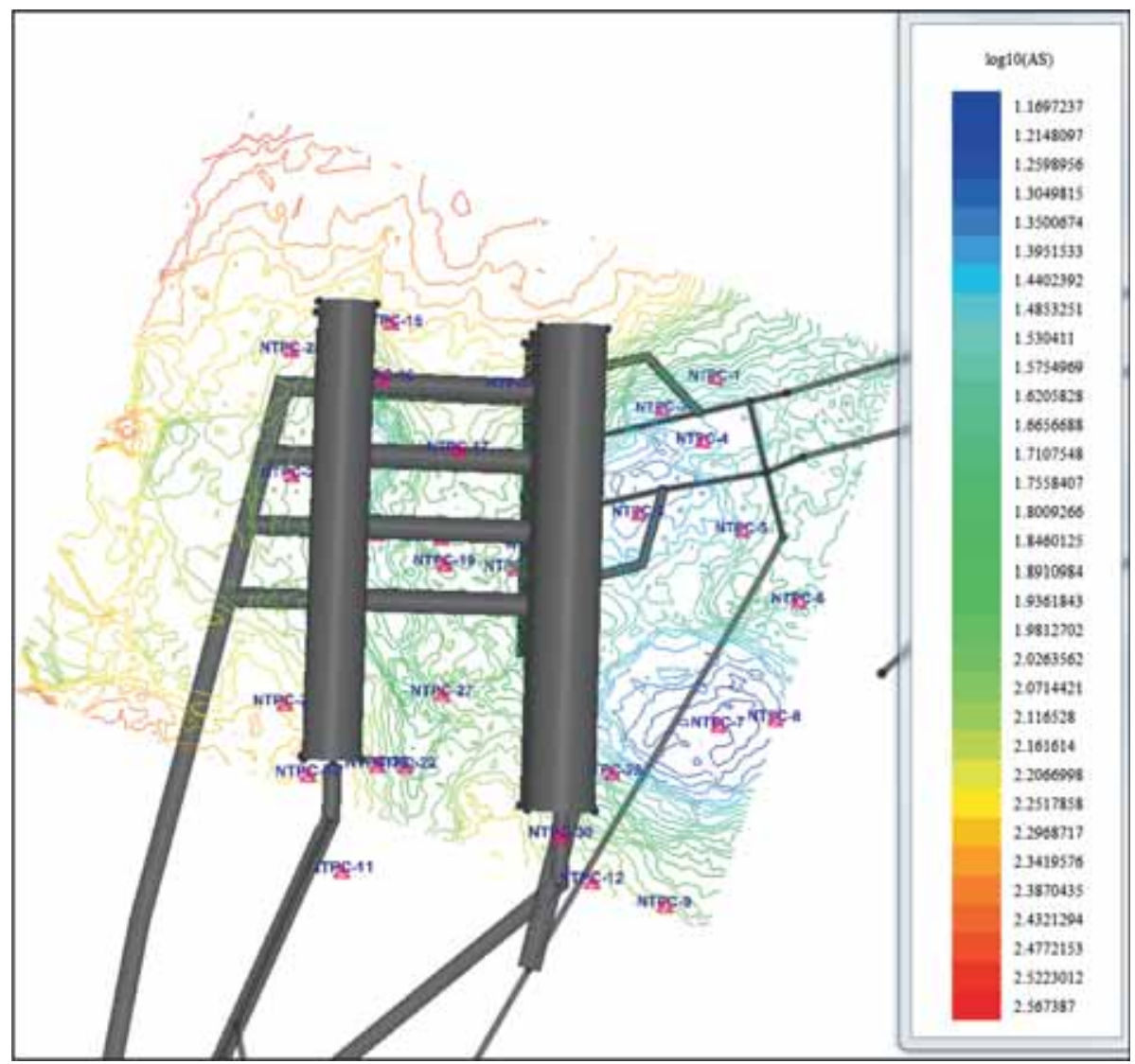

Figure 16. Apparent stress contour. 


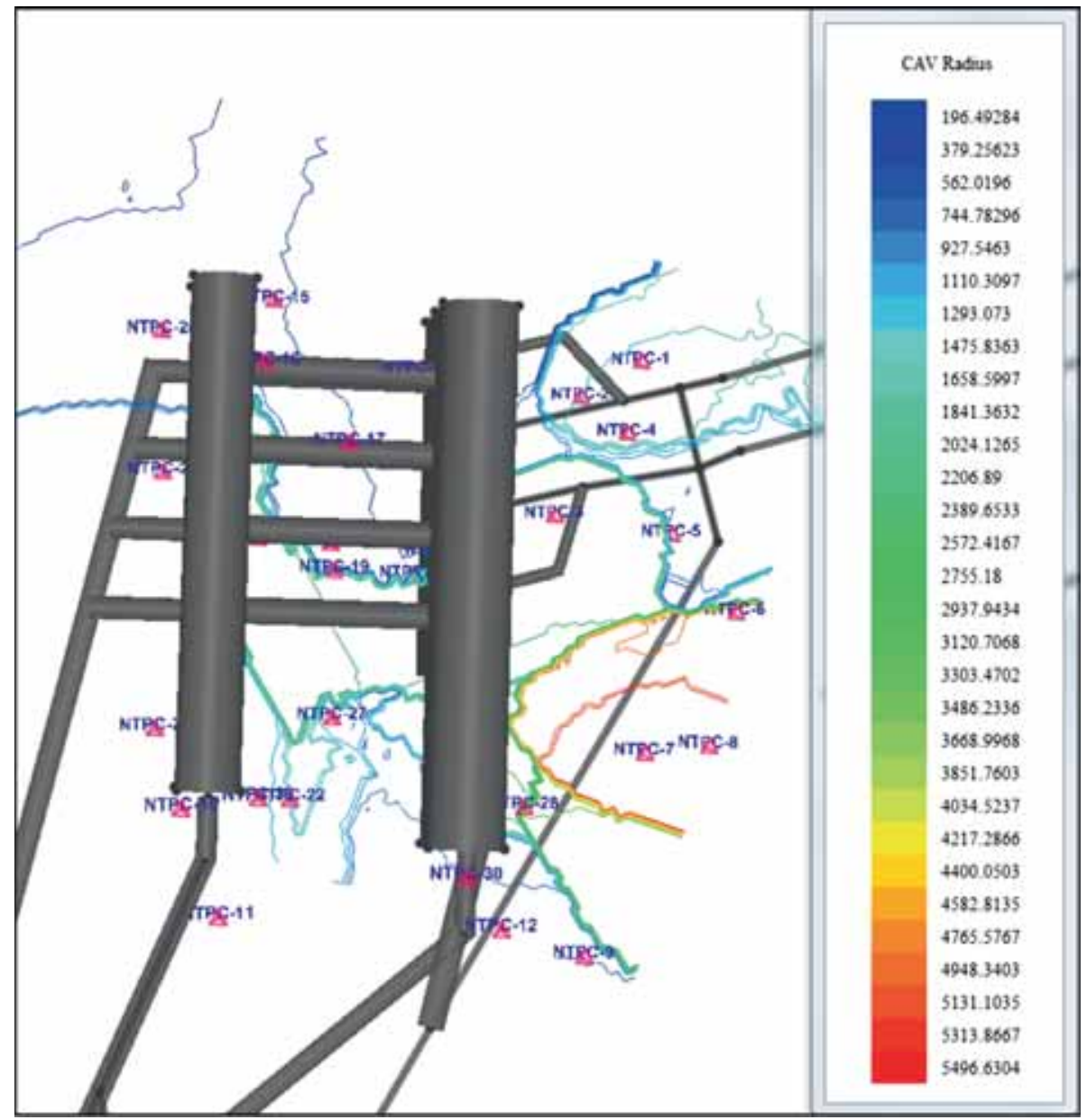

Figure 17. Cumulative apparent volume contour.

\section{Conclusions}

Rock mechanics and rock engineering problems increase under the challenging geological conditions. Such problems increase more in the hydropower projects of the Himalayan region. The present study describes the stability condition of the TVHPP powerhouse cavern located in zone $\mathrm{V}$ of the Himalayan region using microseismic monitoring. Geophones have been installed as per the existing site conditions, status of old cracks and propagation of newly developed cracks in the rockmass cavern. Micro-cracks are located by the microseismic monitoring system whenever they occur in the rockmass cavern of the powerhouse along with the other significant microseismic parameters. During the monitoring period, microseismic network illustrates the three-dimensional picture of micro-cracks distribution and their progress with time. The network successfully detects the precursory of micro-cracks existing in different regions of the powerhouse.
A microseismic network has been used for the study of stress redistribution in different regions of the powerhouse chamber, transformer hall, APS, penstocks, etc. The installed network monitored the stability from the level (elevation) of 1260.0$1330.0 \mathrm{~m}$. Microseismic data processing provided 2254 microseismic events which have been subjected to detailed data analysis and interpretation apart from the daily routine data analysis to understand the stability of rockmass strata. The analysis of primary records provided vital information about the spatial and temporal distribution of microseismic events and its source parameters.

The local magnitude of average recorded events is around -2.25 . Most of the microseismic activities are in the APS, unit pen stocks and at the end of the machine hall. The maximum number of microseismic events released energy between $10 \mathrm{~mJ}$ and $82 \mathrm{~J}$. Due to such little variation in the amount of energy released, there is no rockmass failure. The probability of the recurrence of microseismic events 
of magnitude -0.1 is approximately 90 days inside the powerhouse.

An attempt was made to correlate the microseismic activity with the stability of the structure and existing geological features in the cavern. It has been found that the weak zone in the rockmass cavern and especially the intersection of shear seam and shear zone is the potential fracture zone. This intersection releases more number of events in comparison with the other areas of the powerhouse. This provides a correlation between the intersection of the shear seam and the shear zone of the powerhouse with a cluster of microseismic events. Five clusters of events occurred in the powerhouse during the monitoring period. As a consequence of this, these zones have high displacement. In these clusters, the centre of APS has the highest cumulative apparent volume. The end wall of the machine hall and transformer hall has a higher apparent stress in comparison with the other areas of the powerhouse. But there are no significant changes in apparent stress in any zone of the powerhouse and this indicates that the rockmass cavern is stable during the monitoring period. The occurrence of a high number of microseismic events indicates that the powerhouse requires a continuous real-time microseismic monitoring.

\section{Acknowledgements}

The authors are thankful to the director, NIRM for the necessary support and permission to publish this work. The authors are grateful to NTPC Ltd. for providing the funds, access and logistic support for this study. The quality of the manuscript has been improved after including the valuable suggestions of the reviewers and Dr Biju John, scientist, NIRM. The support of the scientists of NIRM especially of Dr P C Jha, Dr Yogendra Singh, Dr Divyalakshmi K S and Mr Aditya Mishra and executives of the NTPC directly or indirectly is also acknowledged. We sincerely thank Dr Iram Saba Amin for editing and proofreading.

\section{References}

Behera P K 1989 Ultradeep mining problems in Kolar gold mines; In: Rock at great depth (eds) Maury V and Fourmaintraux D, Balkema, Rotterdam, ISBN 9061919754.

Bennett T J and McLaughlin K L 1997 Seismic characteristics and mechanism of rockbursts for use in seismic discrimination; In: Proceedings of the fourth symposium on rockburst and seismicity in mines, RASiM4, Poland, pp. 61-66.

Bureau of Indian Standards, IS 1893: (Part 1) 2002 Indian standard criteria for earthquake resistant design of structures, Part 1; General provisions and buildings (Fifth Revision), New Delhi.

Célérier J, Mark Harrison T, Webb A A G and An Y 2009 The Kumaun and Garhwal Lesser Himalaya, India: Part 1. Structure and stratigraphy; GSA Bull. 121(9-10) 12621280, https://doi.org/10.1130/B26344.1.

Chun'an T, Jimim W and Jingjian Z 2010 Preliminary engineering application of microseismic monitoring technique to rockburst prediction in tunneling of Jinping II project; J. Rock Mech. Geotech. Eng. 2(3) 193-208.

Durrheim R J, Anderson R L, Cichowicz A, EbrahimTrollope R, Hubert G, Kijko A, McGarr A, Ortlepp W D and Van Der Merwe N 2011 Risks posed by large seismic events in the gold mining districts of South Africa; Daya Publishing House, ISBN: 9788170357599.

Essrich F 2005 Mine seismology for rock engineers-an outline of required competencies; In: Proceedings of the sixth international symposium on rockbursts and seismicity in mines, Perth, Western Australia (9-11 March 2005) (eds) Potvin Y and Hudyma M, Australian Centre for Geomechanics, pp. 359-364.

Feng D, Biao L, Nuwen X, Yongguo Z and Peiwei X 2015 Stability evaluation on surrounding rocks of underground powerhouse based on micro seismic monitoring; Shock Vib. Article ID 937181, 9p., https://doi.org/10. 1155/2015/937181.

Geological Survey of India 2000 Seismotectonic atlas of India and its environs; Special Publication no. 59.

Guha S K 1982 Seismological study of the rockbursts at the Kolar Gold Field, India; In: Proceedings of IV congress international association of engineering geology, Vol. IV, New Delhi, India.

Ma T H, Tang C A, Tang L X, Zhang W D and Wang L 2015 Rockburst characteristics and microseismic monitoring of deep-buried tunnels for Jinping II Hydropower Station; Tunneling Underground Space Technol. 49 345-368.

Mendecki A J 1997 Quantitative seismology and rock mass stability; In: Seismic monitoring in mines, Chapman and Hall, Cambridge.

Nuwen X, Chun'an T, Hong L and Zhengzhao L 2012 Application of Microseismic Monitoring Technique in Hydroelectric Projects; In: Hydropower - Practice and Application (ed.) Samadi-Boroujeni H, ISBN: 978-953-510164-2.

Panigrahi R K 2013 Rock dynamics and fracture studies for hill rock slope; In: Proceedings of Indian geotechnical conference, Roorkee, India.

Scott D F, Williams T J and Friedel M J 1997 Investigation of a rockburst site, sunshine mine, Kellog, Idaho; In: Proceedings of the fourth symposium on rockburst and seismicity in mines, RASiM4, Poland, pp. 311-315.

Wilson B, Fred L and Wilbur I D 1974 Microseismic techniques for monitoring the behaviour of rock structures; Bureau of Mines, United States Department of the Interio, 665p. 